\title{
Eco-friendly methods of reducing the consequences of winter maintenance in urban green areas
}

\author{
Anna Bach, Bożena Pawłowska, Małgorzata Pietrzak \\ Department of Ornamental Plants \\ Faculty of Horticulture, University of Agriculture in Krakow \\ 29 Listopada 54, 31-425 Kraków, Poland \\ e-mail: robach@cyf-kr.edu.pl
}

Key word s: alkalization, de-icing, measures, salinity, urban trees

\begin{abstract}
Trees play a crucial role in the urban environment. They fulfil aesthetic, sociocultural, ecological, health-promoting and economic functions. Urban development and related human activity bring many risks to green areas within urban space. Plants are exposed to stress connected with water, soil and air pollution. Living space, harmful light and thermal conditions, drought, high density and changeable soil $\mathrm{pH}$ with excessive salinity are further disadvantages. European and Northern American cities have to cope with a serious danger of tree death. A leading cause is the use of de-icing chemicals in winter, particularly sodium chloride, applied due to its cost-effectiveness and availability.

The paper describes traditional de-icing chemicals used in urban areas $(\mathrm{NaCl}$, solid aggregates, $\mathrm{CaCl}_{2}, \mathrm{MgCl}$ sulphates $-\mathrm{MgSO}_{4},\left(\mathrm{NH}_{4}\right)_{2} \mathrm{SO}_{4}$, urea alcohols and glycols - isopropyl alcohol, ethylene glycol, methanol) and newly developed sodium chloride substitutes (calcium magnesium acetate CMA), sodium formate and acetate $-\mathrm{NaFo} / \mathrm{NaAc}$, potassium carbonate $-\mathrm{K}_{2} \mathrm{CO}_{3}$ ). Moreover, prophylactic
\end{abstract}


methods aimed at preventing the negative impact of de-icing campaigns, rules of planning and design of urban landscape, and reasonable management measures and pro-ecological modern technologies reducing and reversing the consequences of harmful actions are presented.

\section{INTRODUCTION}

Trees play a crucial role in the urban environment, fulfilling aesthetic, sociocultural, ecological, health-promoting or economic functions. Urban development and related human activity bring many hazards to green areas within urban space. Plants are exposed to stress related to water, soil and air pollution. Limited living space, disadvantageous light and thermal conditions, drought, excessive density, fluctuating soil $\mathrm{pH}$ and superfluous salinity are other dangers. European and North American cities have to cope with a serious problem of tree death. This is mostly caused by the use of de-icing chemicals in winter, of which sodium chloride is the most frequently used due to its cost-effectiveness and availability. Ions of this salt alter physicochemical properties of soil, devastating its structure, blocking assimilability of important nutrients and contributing to urban soil alkalization. Symptoms of salt accumulation in soil and salt aerosol deposition on plant organs include: shoot dieback, necrosis of leaf blade edges, premature leaf drop, branch and bough dieback. An increasing salt concentration in connection with difficult urban conditions and lack of efficient countermeasures has led to the death of many valuable street trees.

This paper presents prophylactic measures aimed at counteracting the negative impact of "winter campaigns", and outlines planning and design principles, as well as eco-friendly modern technologies able to reduce salt use in winter and to reverse the effects of inappropriate actions. De-icing agents are characterized as well.

\section{ROLE AND SIGNIFICANCE OF TREES IN CITIES}

Trees inscribed in the urban landscape play a number of important roles. There are huge advantages of tree presence in urbanized terrains, while negative aspects seem to be of minor significance and are due to incorrect choice of tree species and location. A multitude of functions and advantages of urban green areas speaks decidedly for their expansion and conservation (Czerwieniec and Lewińska 1996, Szczepanowska 2001, Saebo et al. 2003, Tyrvainen et al. 2005). The aesthetic and architectural role is an important function of trees in cities. By their diversity, they enrich the landscape and differentiate the perception of colour, structure and density of the surroundings depending on the season (Tyrvainen et al. 2005). Urban 
trees also present social advantages, supporting mental and physical health. Healthpromoting properties have been demonstrated for some species of shrubs and trees, e.g. Betula sp., Tilia sp., Picea sp., due to their negative ionization of air, which is beneficial for human well being (Czerwieniec and Lewińska 1996). The economic benefits of the presence of trees in cities also cannot be disregarded. Depending on age, species and size of tree crown, trees can influence the value of properties in which they grow (Tyrvainen et al. 2005, Akbari et al. 2001). Trees show an exceptional ability to purify the urban environment (Beckett et al. 1998). They increase humidity and by transpiration and shading, they slightly lower local air temperature and thus ozone level, which tends to accumulate in places with higher temperatures (Randrup et al. 2000). Trees minimize the negative impact of wind, fulfilling a role of windbreaks along streets and motorways (Tyrvainen et al. 2005). They alleviate the impact of heavy rain by keeping raindrops on their leaves, thereby reducing run-off to drainage systems and minimizing the risk of flooding (Szczepanowska 2001). In addition, they provide protection from the sun, filtering much of the UV radiation reaching the earth's surface (Randrup et al. 2000). In combination with soil banks and other structures, trees constitute a soundabsorbing barrier, which is important particularly along thoroughfares and motorways (Czerwieniec and Lewińska 1996). Furthermore, trees are an oasis of biodiversity, securing feed and shelter for invertebrates, birds and mammals (Tyrvainen et al. 2005).

\section{CHARACTERIZATION OF DE-ICING AGENTS USED FOR WINTER MAINTENANCE}

Excessive salt concentration along streets adversely affects all components of vegetation: trees, shrubs, herbaceous annuals and perennials (Dobson 1991). Different reactions by plants to salt stress and other negative urban influences are particularly conspicuous in perennial plants, like trees and shrubs (Hofstra et al. 1979), which accumulate harmful ions in their tissues. Trees are very important to the urban environment but also sensitive to accumulating stress, with coniferous being less resistant than deciduous trees (Borowski and Latocha 2006).

\section{Problems related to the use of sodium chloride $(\mathrm{NaCl})$}

Sodium chloride, commonly known as table salt, was first used as a de-icing agent in the 1930s in the United States (Ramakrishna and Viraraghavam 2005). In Poland, in 1968 de-icing chemicals replaced aggregate, used earlier to counteract road slipperiness (Czerwiński 1978). Sodium chloride, due to its efficiency, availability in the market and low price, even now is the most often used de-icing agent for roads, pavements, and motorways in the countries where winter 
temperatures oscillate around $0^{\circ} \mathrm{C}$ and below (Dobson 1991). Excessive salt concentration produces such consequences as surface water pollution (Thunqvist 2003) and soil degradation, leading to its lesser permeability to water and gases (Ramakrishna and Viraraghavam 2005), and to the release of heavy metals from insoluble complexes in soil (Oberts et al. 2000). Moreover, further adverse effects of sodium chloride include: corrosion of metals and asphalt, and concrete deterioration and thus damage of the surface of roads, pavements, bridges, driveways and other objects (Cody et al. 1996). Sodium chloride applied to roads and pavements in an automated way using specialized equipment or manually enters the environment in which street plants live. Salt from road or pavement surfaces is redistributed through the air or by the water/soil route, which is facilitated by splashing salinated slush by passing cars, by wind, melted snow runoff from road or pavement surfaces, clearing of sodium chloride-contaminated snow from roadsides, and dispersion of salt molecules in air as aerosol and later deposition on street objects and plants (Sieghart et al. 2005).

\section{Other de-icing agents}

Apart from sodium chloride, there are other substances that possess de-icing properties; however, their use is not common due to lower efficacy, higher cost or negative environmental impact.

\section{Conventional de-icing agents (Dobson 1991)}

Solid aggregates (sand, gravel) are cheap, easily available, have little or no negative environmental impact. However, they are relatively inefficient and repeated application is required for better efficacy. In addition, they can clog drains and cause car corrosion, while gravels splashed by cars can be risky for passers.

Calcium chloride $\mathrm{CaCl}_{2}$ immediately thaws ice and a desired effect can be achieved with smaller amounts of this compound than $\mathrm{NaCl}$, and it has a lower freezing point $\left(-51.6^{\circ} \mathrm{C}\right)$ in comparison with $\mathrm{NaCl}\left(-21.1^{\circ} \mathrm{C}\right)$. A disadvantage is high hygroscopicity (problems with storage and application) and higher price than $\mathrm{NaCl}$.

Magnesium chloride $\mathrm{MgCl}_{2}$ (and $\mathrm{KCl}$ with similar properties) freezes at $-33^{\circ} \mathrm{C}$ and enriches the environment with calcium ions (macroelement). However, it is strongly hygroscopic and can be used only in a dissolved form and requires specialized equipment. It is more expensive than $\mathrm{NaCl}$ and very corrosive.

Sulfates: $\mathrm{MgSO}_{4},\left(\mathrm{NH}_{4}\right)_{2} \mathrm{SO}_{4}$ possess excellent de-icing properties but cause mortar and concrete surface deterioration. $\left(\mathrm{NH}_{4}\right)_{2} \mathrm{SO}_{4}$ is rich in nitrogen, posing a risk of overfertilization and ground water pollution.

Urea does not cause corrosion but is a very expensive preparation, and is efficient to $-12^{\circ} \mathrm{C}$. It is light and can be easily blown away so it can be applied after prior 
moisturizing. The product of its decomposition, ammonia, is toxic to aquatic fauna. It can also cause overfertilization.

Alcohols and glycols (izopropyl alkohol, ethylene glycol) are usually used on runways, do not cause corrosion but are more expensive than $\mathrm{NaCl}$. They are effective at temperature higher than $-5^{\circ} \mathrm{C}$. They can produce surface damage.

Methanol does not cause corrosion, freezes at $-120^{\circ} \mathrm{C}$. It is easy to use in liquid form but is highly flammable. Its high price is compensated by its weaker adverse environmental impact.

\section{Newly developed $\mathrm{NaCl}$ substitutes}

Calcium magnesium acetate CMA was implemented in the USA at the beginning of the 1980s. It has huge potential because it is friendly to the environment (Robidoux and Delisle 2001).

Sodium formate and acetate $\mathrm{NaFo} / \mathrm{NaAc}$ is an innovative de-icing substance. It is a mixture of sodium formate $(\mathrm{NaFo})$ and sodium acetate $(\mathrm{NaAc})$ discovered in the 1990s. In the USA, it is marketed under the name "Ice Shear". It is not corrosive, and is harmless to fauna and flora (Bang and Johnson 1998).

Potassium carbonate $\mathrm{K}_{2} \mathrm{CO}_{3}$ is an optimal alternative to sodium chloride. Potassium is a deficient element, particularly at high soil salinity, while carbonate anion does not show phytotoxic liability. Its dose of $200 \mathrm{~g} \mathrm{~m}^{-2}$ used in Austria did not produce any negative effects on vegetation (Erhart and Hartl 2000, Hartl and Erhart 2002).

\section{MEASURES REDUCING NEGATIVE IMPACT OF EXCESSIVE SALT CONCENTRATION ON URBAN TREES}

Reduction of salt use by implementation of rational management and new technologies

The consumption of de-icing substances depends on the policies of the local authorities responsible for winter maintenance of roads, pavements and motorways, and their cooperation with contractors (Knudsen 1994). In Copenhagen, new technologies of salt application involve utilization of precise dosing machines adapted to the use of moisturized salt. The dose of the moisturized salt required to achieve a de-icing effect was lower than the dose of dry salt (OECD 1989). A specialized computer program for analysis of weather conditions is another necessary investment aiding the precise estimation of the needed salt dose. The program is linked to stations in different parts of the city that supply information about the amount of salt still remaining on road surfaces and about street moisture (OECD 1989). To prevent excessive salt application, the training of de-icing 
equipment operators is important, and popular campaigns about the negative consequences of superfluous salt use would be helpful (OECD 1989). During heavy snowfall in winter, the snow should be mechanically removed and transported outside of the city to the designated areas. Speed restriction in urban spaces is an efficient method of counteracting the splashing of polluted slush (Sieghart et al. 2005).

\section{Planning and design of urban landscape}

It is very common that trees grow very close to the streets and pavements, having little space, with hard surfaces all around the trunk. There are several methods to adapt urban architecture in order to limit pollutant sedimentation and run-off into the environment where street plants live. One solution is to construct elevated green strips (Craul 1992) and to use barriers like low walls along streets and semicircular forms surrounding the trees that may serve as shields. The proper location of trees is a very important solution protecting them from salt stressinduced damage. When new plants are planned, it is important to keep at least a distance of $2 \mathrm{~m}$ from the roadside if possible, considering existing urban development (Pedersen et al. 2000).

\section{$\underline{\text { Shields around trees }}$}

Low shields $(0.5 \mathrm{~m}$ tall) separating the tree from the roadside, installed in winter and dismantled in spring, can significantly reduce salt accumulation in the root system of plants (Pedersen et al. 2000, Sieghart et al. 2005).

\section{Planning and agrotechnical preparation for urban plantings}

Plants should be selected based on environmental, economic, urbanistic and social criteria (Miller 1997, Saebo et al. 2003). To counteract salt stress development, it is important to select suitable species and varieties of healthy nursery plants (Pauleit 2003). Anthropogenically transformed urban soil is characterized by weakly developed biological life, and the lack of mycorrhizal organisms can limit the growth of trees, particularly from street plantings, by hindering absorption of nutrients. Inoculation of excessive salinity-resistant mycorrhizal fungi in the root system of plants can significantly improve the tolerance of sensitive trees, like Tilia cordata, Fagus sylvatica and Aesculus pavia, to salt accumulation in soil (Borowski and Latocha 2006, Chohura 2007). The preparation of substrate is also important. This can require the replacement of degraded soil and the use of soil supplementation with substrates (e.g. hydrogels) able to increase water and nutrient accumulation potential. Investment in watering/drainage or aerating/watering systems is also worth consideration (Szczepanowska 2001, Kosmala 2005). 
Breeding for better genotype of trees

Breeding studies can lead to genetic improvement of trees and their resistance to salinity, and although this is a time-consuming and difficult process, it can be a way to ensure the future survival of trees under difficult urban conditions (Allen et al. 1994, Sieghart et al. 2005, Borowski and Latocha 2006).

Soil desalination

The health of trees can be improved by the application of calcium sulfate $\left(\mathrm{CaSO}_{4}\right)$, washing salt away from soil, mulching and fertilization, and soil replacement (Dobson 1991, Craul 1992, Szczepanowska 2001, Sieghart et al. 2005).

\section{CONCLUSIONS}

Observations of trees along thoroughfares in Krakow carried out between 20042007 have demonstrated that tree dieback is a serious problem affecting a majority of species sensitive to difficult urban conditions. The studies identified the use of sodium chloride as a de-icing agent as the main contributing factor to this phenomenon. A similar negative effect of $\mathrm{NaCl}$ was confirmed by observation of street trees and shrubs, and chemical analyses of soil and plant organs from other Polish and European cities (Czerwiński 1978, Simini and Leone 1986, Dmuchowski et al. 2002, Dmuchowski and Badurek 2004, Bach and Pawłowska 2006).

To save dying trees, it is important to counteract the salt accumulation around plant root systems by applying the following measures: informing the public about the negative consequences of salt accumulation in the environment (OECD 1989), training of de-icing equipment operators, instructing people applying salt to pavements adjacent to private properties, and the use of environment-friendly sodium chloride substitutes, like calcium-magnesium acetate. Moreover, urban landscapes should be properly designed, using suitable resistant plant species (Robinia pseudoacacia, Platanus hispanica, Acer campestre, Prunus $\times$ eminens). Plantings should be recorded in detail and trees should be monitored, particularly in terms of their health condition. The proper agrotechnical preparation of substrate and maintaining it in good condition is also indispensable. Trees growing at sites highly polluted by salt can be helped by building low fences, walls and elevated pavements, separating the plants from roadway, and special shields around the trees. In spring, salt can be washed away from soil and gypsum can be applied as a remedy. The exchange of experiences with other countries is necessary as well. 


\section{REFERENCES}

Akbari H., Pomerantz M., TAha H., 2001. Cool surfaces and shade trees to reduce energy use and improve air quality in urban areas. Solar Energy 70(3): 295-310.

Allen J.A., Chambers J.L., Stine M., 1994. Prospects for increasing the salt tolerance of forest trees: a review. Tree Physiol. 14(7-9): 843-853.

BACH A., PAWŁOWSKA B., 2006. Effect of sodium chloride salinity and pH of soil on ornamental urban trees in Krakow with regard to nature conservation in cities. Ecol. Chem. Eng. 13(6): 455-461.

BANG S., JOHNSON D., 1998. Environmental effects of sodium acetate/formate deicer, Ice Shear. Archives Environ. Contam. Toxicol. 35: 580-587.

BECKETT K.P., FREER-SMith P.H., TAYLOR G., 1998. Urban woodlands: their role in reducing the effects of particulate pollution. Environ. Poll. 99(3): 347-60.

Borowski J., LATOCHA P., 2006. Dobór drzew i krzewów do warunków przyulicznych Warszawy i miast centralnej Polski - Trees and shrubs suitable for street conditions in Warsaw and other cities in central Poland. Roczn. Dendrol. 54: 83-93.

ChohuRA P., 2007. Nawożenie roślin w terenach zieleni publicznej. VIII Ogólnopol. Konf. „Zielone miasto - nieodkryte możliwości”. Warszawa, 23-24 sierpnia: 63-70.

CODY D.R., CODY M.A., SpRY G.P., GAN G.L., 1996. Concrete deterioration by deicing salts: an experimental study. Centre for Transportation Research and Education. Iowa State University.

Craul J.P., 1992. Urban soil in landscape design. John Wiley \& Sons, Inc: 199-202.

CZERWIENIEC M., LEWIŃSKA J., 1996. Zieleń w mieście. Instytut Gospodarki Przestrzennej i Komunalnej, Warszawa.

CZERWIŃSKI Z., 1978. Wpływ chemicznej technologii odśnieżania ulic na gleby i roślinność drzewiastą aglomeracji miejskich. Zesz. Nauk. SGGW, Warszawa, Rozpr. Nauk. 104: 5-39.

DMUCHOWSKI W., BADUREK M., 2004. Chloride and sodium in the leaves of urban trees in Warsaw in connection to their health condition. Ecol. Chem. Eng. 11(4-5): 297- 303.

DMUChowski W., KurczyŃSKa E., ChMielewsKi W., BADUREK M., 2002. Wzrost i rozwój lipy krymskiej w nasadzeniach przyulicznych. IV Krajowe 
Symp. „Reakcje biologiczne drzew na zanieczyszczenia przemysłowe”. Wyd. Nauk. Poznań: 629-635.

DOBSON M.C., 1991. De-icing salt damage to trees and shrubs. Forestry Commission Bull. 101, London.

ERHART E., HARTL W., 2000. Effects of potassium carbonate as an alternative deicer on ground vegetation and soil. Ann. Appl. Biol. 136(3): 281-289.

HARTL W., ERHART E., 2002. Effects of potassium carbonate as an alternative Road de-icer to sodium chloride on soil chemical properties. Ann. Appl. Biol. 140(3): 271-277.

Hofstra G., Hall R., Lumis G.P., 1979. Studies of salt-induced damage to roadside plants in Ontario. J. Arboricult. 5: 113-115.

KNUDSEN F., 1994. A winter index based on measured and observed road parameters. VII Intl. Road Weather Conf. SIRWEC. Seefeld, Austria, 22-23 March: 1-133.

KoSMALA M., 2005. Najnowsze technologie poprawiające warunki rozwoju drzew przyulicznych w miastach. Architektura. Wyd. Politechniki Krakowskiej: 65-72.

MILLER R.W., 1997. Urban forestry - Planning and managing green spaces. [In:] Selection of trees for urban forestry in the Nordic countries, Saebo A., Benedikz T., and Randrup T.B. (eds). Urban Forestry \& Urban Greening 2(2): 101-114.

OBERTS G., MARSALEK J., VIKLANDER M., 2000. Review of water quality impacts of winter operation of urban drainage. Water Quality Res. J. Canada 35(4): 781-808.

OECD, 1989. Curtailing usage of de-icing agents in winter maintenance. Road Transport Research Program. Organization for Economic Co-operation and Development, Paris.

PAULEIT S., 2003. Urban street tree plantings: identifying the key requirements. Municipal Engineer 156(1): 43-50.

PEDERSEN L.B., RANDRUP T.B., INGERSLEV M., 2000. Effects of road distance and protective measures on deicing $\mathrm{NaCl}$ deposition and soil chemistry in planted median strips. J. Arboricult. 26: 238-245.

RAMAKRISHNA M.D., VIRARAgHAVAN T., 2005. Environmental impact of chemical deicers - a review. Water Air Soil Poll. 166: 49-63.

RANDRUP B.T., MCPHERSON G., SiMPSON R.J. 2000. Urban forest benefit/cost analysis. Draft program for the implementation of an urban forest benefit/cost model in Denmark. Danish Forest and Landscape Res. Institute: 1-64. 
RobidOuX Y.P., DELISLE E.C., 2001. Ecotoxicological evaluation of tree deicers $(\mathrm{NaCl}, \mathrm{NaFo}, \mathrm{CMA})-$ Effect on terrestrial organisms. Ecotoxicol. Environ. Safety 48(2): 128-139.

SAEBo A., BENEDiKZ T., RANDRUP T.B., 2003. Selection of trees for urban forestry in the Nordic countries. Urban Forestry \& Urban Greening 2(2): 101-114.

Sieghart M., Mursh-Radlgruber E., PaOletti E., Couenberg E., Dimitrakopoulus A., Rego F., Hatzistathis A., RANDRUP B.T., 2005. The abiotic urban environment: Impact of urban conditions on Urban Vegetation. [In:] Urban Forests and Trees, Konijnendijk C.C., Nilssson K., and Randrup B.T. (eds): 281-323.

Simini M., LeONE I., 1986. Studies on the effects of de-icing salts on roadside trees. Arboricultural J. 10: 221-231.

SZCZEPANOWSKA H.B., 2001. Drzewa w mieście. Hortpress, Warszawa.

THUNQVIST J.L.E., 2003. Estimating chloride concentration in surface water and groundwater due to deicing salt application. Dept. of Land and Water Resources Engineering, KHT, Stockholm: 1-21.

Tyrvainen L., Pauleit S., SeEland K., VRIES D.S., 2005. Benefits and uses of urban forests and trees. [In:] Urban Forestry and Urban greening, Konijnendijk C.C., Nilsson K., Randrup B.T., and Schipperijn J. (eds): 81-114.

\section{EKOLOGICZNE METODY ZWALCZANIA SKUTKÓW ZIMY W TERENACH ZIELENI}

Streszczenie: Rośliny drzewiaste odgrywają niezmiernie ważną rolę w środowisku miejskim, pełniąc funkcję estetyczną, socjalno-kulturową, ekologiczna, zdrowotną czy też ekonomiczną. Rozwój urbanistyczny i związana z nim działalność człowieka niosą wiele zagrożeń dla zieleni towarzyszącej zabudowie miejskiej. Rośliny są narażone na stresy związane z zanieczyszczeniami wody, gleby i powietrza. Problemem jest ograniczona przestrzeń życiowa i niekorzystne warunki świetlno-termiczne, susza, zagęszczenie i zmiany $\mathrm{pH}$ gleby, jak również nadmierna koncentracja soli. Miasta Europy i Ameryki Północnej borykają się z poważnym zjawiskiem zamierania roślin drzewiastych. Spowodowane jest to głównie stosowaniem chemicznych środków przeciwoblodzeniowych w okresie zimowym, a zwłaszcza najczęściej aplikowanym, ze względu na jego niską cenę, dostępność i efektywność chlorku sodu.

W pracy omówiono tradycyjne środki przeciwoblodzeniowe używane w miastach $\left(\mathrm{NaCl}\right.$, kruszywa stałe, $\mathrm{CaCl}_{2}, \mathrm{MgSO}_{4},\left(\mathrm{NH}_{4}\right)_{2} \mathrm{SO}_{4}$, mocznik, alkohole i glikole - alkohol izopropylowy, glikol etylenowy, metanol) oraz nowoopracowane 
substytuty chlorku sodu (octan wapniowo magnezowy - CMA, mrówczan i octan sodu - NaFo/NaAc, weglan potasu $-\mathrm{K}_{2} \mathrm{CO}_{3}$ ). Ponadto przedstawiono metody profilaktyczne zapobiegające negatywnym skutkom 'walki $\mathrm{z}$ zimą', zasady planowania i projektowania miejskiego krajobrazu, a także sposoby racjonalnego zarządzania oraz proekologiczne, nowoczesne technologie redukujące zużycie soli zimą i niwelujące skutki niewłaściwych działań.

Received November 17, 2008; accepted November 19, 2009 